\title{
Modulation of Serotonergic Function in Rat Brain by VN2222, a Serotonin Reuptake Inhibitor and 5- $\mathrm{HT}_{\text {IA }}$ Receptor Agonist
}

\author{
Luz Romero',3, Pau Celada', Raúl Martín-Ruiz', Llorenç Díaz-Mataix', Marisabel Mourelle², Joaquim \\ Delgadillo ${ }^{2}$, Ildefonso Hervás' and Francesc Artigas*, I \\ 'Department of Neurochemistry, Institut d'Investigacions Biomèdiques de Barcelona, CSIC (IDIBAPS), Barcelona, Spain; ${ }^{2}$ Research \& \\ Development, Vita-Invest S.A. (Grupo Vita), Barcelona, Spain
}

\begin{abstract}
VN2222 ( I-(benzo[b]thiophen-3-yl)-3-[4-(2-methoxiphenyl piperazin- I-y|]propan- I-ol) is a potential antidepressant with high affinity for the serotonin transporter and 5-HTIA receptors. Locally applied, VN2222 enhanced the extracellular 5-hydroxytryptamine (5-HT) concentration $\left(5-\mathrm{HT}_{\text {ext }}\right)$ in rat striatum to $780 \%$ of baseline whereas its systemic administration $(\mathrm{I}-\mathrm{I} 0 \mathrm{mg} / \mathrm{kg} \mathrm{s.c}$.$) reduced 5-\mathrm{HT}$ ext. In the presence of citalopram, 8-OH-DPAT or VN2222 applied in medial prefrontal cortex reduced 5-HT ext. Fluoxetine, VN2222, and 8-OHDPAT suppressed the firing rate of dorsal raphe 5-HT neurons (ED50: 790, 14.9, and $0.8 \mu \mathrm{g} / \mathrm{kg}$ i.v., respectively). These effects were antagonized by WAY 100635. Administration of VN2222 for 2 weeks desensitized 5-HT IA receptors as assessed by microdialysis and single-unit recordings ( $E_{50}$ values for $8-\mathrm{OH}$-DPAT were 0.45 and $2.34 \mu \mathrm{g} / \mathrm{kg}$ i.v. for controls and rats treated with $6 \mathrm{mg} / \mathrm{kg}$ day VN2222). These results show that VN2222 is a mixed $5-\mathrm{HT}$ reuptake inhibitor/5-HT IA agonist that markedly desensitizes $5-\mathrm{HT}_{\text {IA }}$ autoreceptors. These properties suggest that it may be a clinically effective dual action antidepressant drug. Neuropsychopharmacology (2003) 28, 445-456. doi:I 0.1038/sj.npp. 1300062
\end{abstract}

Keywords: 5-HTIA receptors; 5-hydroxytryptamine uptake; antidepressant drugs; dorsal raphe; selective serotonin reuptake inhibitors (SSRIs); frontal cortex

\section{INTRODUCTION}

The selective serotonin (5-hydroxytryptamine, 5-HT) reuptake inhibitors (SSRI) have become the most widely prescribed antidepressant drugs because of their relative absence of severe side effects. Their efficacy is comparable to that of tricyclic antidepressants (Tollefson et al, 1994), although the latter may be more effective in severely depressed inpatients (Danish University Antidepressant Group, 1986, 1990). The increase in the synaptic concentration of 5-HT that follows reuptake inhibition is limited by a negative feedback involving $5-\mathrm{HT}_{1 \mathrm{~A}}$ autoreceptors (Adell and Artigas, 1991; Artigas et al, 1996). Following repeated treatment, $5-\mathrm{HT}_{1 \mathrm{~A}}$ receptors desensitize (Blier and de Montigny, 1994; Invernizzi et al, 1994; Hervás et al, 2001). This effect results in a reduced efficacy of the negative feedback and therefore in an increase of the extracellular concentration of $5-\mathrm{HT}\left(5-\mathrm{HT}_{\text {ext }}\right)$ in the forebrain (Bel and

\footnotetext{
*Correspondence: Dr F Artigas, Department of Neurochemistry, Institut d'Investigacions Biomèdiques de Barcelona, CSIC (IDIBAPS), Rosselló |6I, 08036 Barcelona, Spain, Tel: +3493 363 8315, Fax: +3493363830 I, E-mail: fapnqi@iibb.csic.es

${ }^{3}$ Present address: Laboratorios Dr Esteve, 0804। Barcelona, Spain. Received 4 June 2002; revised 2 August 2002; accepted 7 August 2002 Online publication: 9 August 2002 at http://www.acnp.org/citations/ Npp080902366
}

Artigas, 1993; Invernizzi et al, 1994; Rutter et al, 1994; Kreiss and Lucki, 1995).

To overcome the above negative feedback and hasten the clinical action of SSRIs, the use of $5-\mathrm{HT}_{1 \mathrm{~A}}$ receptor antagonists, in combination with SSRI, was proposed (Artigas, 1993). In keeping with this hypothesis, selective (eg WAY 100635) and nonselective $5-\mathrm{HT}_{1 \mathrm{~A}}$ receptor antagonists have been shown to potentiate the increase in $5-\mathrm{HT}_{\text {ext }}$ produced by antidepressant drugs in the rat brain (see Artigas et al, 1996 for review). At the clinical level, several open-label (Artigas et al, 1994; Blier and Bergeron, 1995; Bakish et al, 1997) and placebo-controlled trials (Maes et al, 1996; Pérez et al, 1997; Tomé et al, 1997; Zanardi et al, 1997, 1998; Bordet et al, 1998; Maes et al, 1999) have shown a faster action and/or greater efficacy of SSRIs when given in combination with the nonselective $5-\mathrm{HT}_{1 \mathrm{~A}}$ receptor antagonist pindolol. However, the efficacy of pindolol in chronically ill or treatment-resistant patients is questionable (Moreno et al, 1997; Tomé et al, 1997; Berman et al, 1999; Pérez et al, 1999).

In vivo, pindolol appears to display a preferential antagonism of pre- $v s$ postsynaptic $5-\mathrm{HT}_{1 \mathrm{~A}}$ receptors in the rat brain (Romero et al (1996), Tada et al (1999), see however Corradetti et al, 1998). This may be related to its preferential occupancy of presynaptic $5-\mathrm{HT}_{1 \mathrm{~A}}$ receptors, as assessed by positron emission tomography scanning in rat 


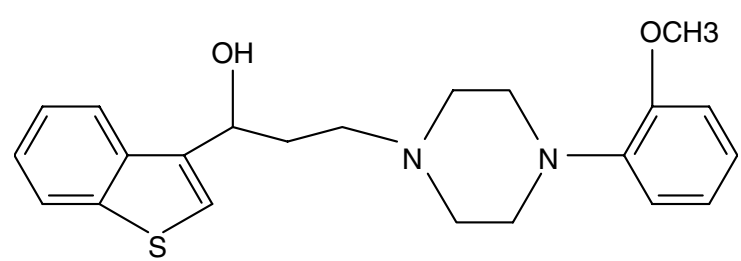

Figure I Chemical structure of VN2222, ( \pm ) I-(benzo[b]thiophen-3yl)-3-[4-(2-methoxiphenyl piperazin- I-yl]propan- I-ol.

and human brains (Hirani et al, 2000; Rabiner et al, 2000; Martinez et al, 2000). However, pindolol displays higher affinity for $\beta$-adrenoceptors than for $5-\mathrm{HT}_{1 \mathrm{~A}}$ receptors, which has led to the development of pure $5-\mathrm{HT}_{1 \mathrm{~A}}$ antagonists or compounds with a dual 5-HT reuptake blockade/5- $\mathrm{HT}_{1 \mathrm{~A}}$ receptor antagonist action. Yet, given the involvement of hippocampal postsynaptic $5-\mathrm{HT}_{1 \mathrm{~A}}$ receptors in the antidepressant effects of SSRIs (Blier and de Montigny, 1994; Haddjeri et al, 1998) there is some concern that the use of $5-\mathrm{HT}_{1 \mathrm{~A}}$ receptor antagonists not discriminating between pre- and postsynaptic $5-\mathrm{HT}_{1 \mathrm{~A}}$ receptors could cancel the benefits of enhancing presynaptically the 5-HT function. Moreover, recent data suggest that antidepressant drugs increase neurogenesis in the rat brain (Malberg et al, 2000 ), an effect that could be mediated by the activation of $5-\mathrm{HT}_{1 \mathrm{~A}}$ receptors (Gould, 1999). Therefore, an alternative approach would be the use of drugs with dual 5-HT reuptake blockade/5- $\mathrm{HT}_{1 \mathrm{~A}}$ receptor agonist action. These could desensitize presynaptic $5-\mathrm{HT}_{1 \mathrm{~A}}$ receptors by virtue of their action at raphe $5-\mathrm{HT}_{1 \mathrm{~A}}$ autoreceptors. At the same time, they could enhance serotonergic transmission through the activation of postsynaptic $5-\mathrm{HT}_{1 \mathrm{~A}}$ receptors and, unlike selective $5-\mathrm{HT}_{1 \mathrm{~A}}$ receptor agonists, they could keep the tone on other postsynaptic 5-HT receptors because of their ability to inhibit 5-HT reuptake. The present study reports on the in vivo effects of one such compound (VN2222; $( \pm$ )(1-(benzo[b]thiophen-3-yl)-3-[4-(2-methoxiphenylpiper azin-1-yl]propan-1-ol, Figure 1) (Martínez-Esparza et al, 2001) on the serotonergic system in rat brain using microdialysis and single-unit extracellular recordings.

\section{MATERIALS AND METHODS}

\section{Animals}

Male Wistar rats (Iffa Credo, Lyon, France) weighing 250$320 \mathrm{~g}$ at the time of experiments were used. Rats used in chronic treatments had a weight of $175 \mathrm{~g}$ at arrival and typically reached $250 \mathrm{~g}$ at the time of experiments. Animals were kept in a controlled environment $(12 \mathrm{~h}$ light-dark cycle and $22 \pm 2{ }^{\circ} \mathrm{C}$ room temperature). Food and water were provided ad libitum before and during the experiments. Animal care followed the European Union regulations (OJ of EC L358/1 18/12/1986).

\section{Drugs and Treatments}

5-HT, 8-OH-DPAT [8-hydroxy-2-(di-n-propylamino) tetralin], DOI (1-[2,5-dimethoxy-4-iodophenyl-2-aminopropane]), fluoxetine, and WAY 100635 [N-(2-(4-(2-methoxyphenyl)-1-piperazinyl)ethyl)- $N$-(2-pyridyl) cyclohexanecarboxamide.3HCl] were from RBI (Natick, MA). p-chlorophenylalanine methyl ester (PCPA) was from Sigma (St Louis, MO). Citalopram $\mathrm{HBr}$ was kindly provided by Lundbeck A/S. VN2222 was synthesized by VITA-INVEST (Sant Joan Despí, Barcelona, Spain). Concentrated stock solutions were prepared and aliquots were stored at $-80^{\circ} \mathrm{C}$. Working solutions were prepared daily by dilution. For local administration of drugs, these were dissolved in the dialysis fluid and applied by reverse dialysis at the stated concentrations (uncorrected for probe recovery). Systemic administration of VN2222 was performed s.c. at the stated doses in 10\% Tween 80. 8-OH-DPAT and WAY 100635 were injected s.c. dissolved in saline. An additional experiment in which we examined the effects of the sustained administration of fluoxetine $(3 \mathrm{mg} / \mathrm{kg}$ day, dissolved in $50 \%$ DMSO) and $\mathrm{VN} 2222(6 \mathrm{mg} / \mathrm{kg}$ day, dissolved in DMSO) was carried out in which these drugs were administered with minipumps following described procedures (Hervás et al, 2001). Control rats were treated with vehicle.

In electrophysiological experiments, 8-OH-DPAT, fluoxetine, WAY 100635, and VN2222 were administered i.v. through the femoral vein. In experiments assessing the changes in $5-\mathrm{HT}_{1 \mathrm{~A}}$ receptor sensitivity produced by the chronic treatment with VN2222, rats were injected twice daily $(12 \mathrm{~h}$ apart) for 2 weeks with the drug $(2 \times 3$ or $2 \times 10 \mathrm{mg} / \mathrm{kg}$ s.c.) or vehicle. The same treatment schedule was used to examine the effects of 2-week administration of fluoxetine $(3 \mathrm{mg} / \mathrm{kg}$ day). Microdialysis experiments were performed on the second day after the last drug injection to avoid residual effects of the drug. The sensitivity of $5-\mathrm{HT}_{1 \mathrm{~A}}$ receptors was also examined using single-unit recordings. These were performed 1 day after microdialysis (3-day washout) to assess the sensitivity of $5-\mathrm{HT}_{1 \mathrm{~A}}$ receptors by both techniques in the same rats. Yet, owing to the greater experimental requirements of electrophysiological $v s$ microdialysis experiments, single-unit recordings could not be performed in all rats. We report on electrophysiological data from two complete groups (rats treated with vehicle and $6 \mathrm{mg} / \mathrm{kg}$ day VN2222, $n=7$ and 5, respectively) and two rats treated with $20 \mathrm{mg} / \mathrm{kg}$ day VN2222.

\section{Surgery and Microdialysis Procedures}

Microdialysis procedures were performed essentially as described previously (see updated procedure in Adell and Artigas, 1998). In brief, anesthetized rats (pentobarbital $60 \mathrm{mg} / \mathrm{kg}$ i.p.) were stereotaxically implanted with I-shaped probes in the dorsal striatum or medial prefrontal cortex. The stereotaxic coordinates (in $\mathrm{mm}$, with respect to bregma and duramater; Paxinos and Watson, 1986) were: prefrontal cortex (AP +3.4, L $-0.8, \mathrm{DV}-6.0$, probe tip: $4 \mathrm{~mm})$, dorsal striatum (AP $+0.2, \mathrm{~L}-3.0$, DV -8.0 , probe tip $4 \mathrm{~mm}$ ). Animals were allowed to recover from surgery for $20-24 \mathrm{~h}$ and then probes were perfused with artificial CSF $(125 \mathrm{mM}$ $\mathrm{NaCl}, 2.5 \mathrm{mM} \mathrm{KCl}, 1.26 \mathrm{mM} \mathrm{CaCl}_{2}$, and $1.18 \mathrm{mM} \mathrm{MgCl}_{2}$ ) pumped at $0.25 \mu \mathrm{l} / \mathrm{min}$. When required by the experimental paradigm, the dialysis fluid was supplemented with 1 or $10 \mu \mathrm{M}$ citalopram. Sample collection started $60 \mathrm{~min}$ after the beginning of perfusion. Dialysate samples were collected every $20 \mathrm{~min}(5 \mu \mathrm{l})$. Usually $5-6$ fractions were collected before drug administration, of which four were used to obtain the individual basal values. At the end of the experiments, rats were killed by an overdose of anesthetic 
and the placement of the dialysis probes was checked by perfusing Fast Green dye and visual inspection of the probe track after cutting the brain at the appropriate levels.

\section{Biochemical Analyses}

The concentration of 5-HT in dialysates was determined using a modification of an HPLC method previously described (Adell and Artigas, 1998). 5-HT was also determined in homogenates of frontal cortex of control rats and of rats treated with PCPA $(350 \mathrm{mg} / \mathrm{kg}, 2$ days before). Briefly, after removal of the brains from the skull, pieces of frontal cortex were rapidly dissected out on ice, weighed, and stored frozen $\left(-80^{\circ} \mathrm{C}\right)$. Brain tissue was ultrasonically homogenized (15-20 s) in cold perchloric acid $(0.4 \mathrm{~mol} / \mathrm{l})$ containing $0.1 \%$ sodium metabisulfite, $0.01 \%$ EDTA, and $0.01 \%$ cysteine. After centrifugation (10 min, $10000 \mathrm{~g}$ ) aliquots of supernatants were analyzed by HPLC. The composition of HPLC eluant was as follows: $0.15 \mathrm{M}$ $\mathrm{NaH}_{2} \mathrm{PO}_{4}, 1.3 \mathrm{mM}$ octyl sodium sulfate, $0.2 \mathrm{mM}$ EDTA (pH 2.8 adjusted with phosphoric acid), plus $27 \%$ methanol. 5HT was separated on a $3 \mu \mathrm{m}$ ODS 2 column $(7.5 \times 0.46 \mathrm{~cm}$; Beckman, San Ramon, CA) and detected amperometrically with a Hewlett-Packard 1049 detector (oxidation potential $+0.6 \mathrm{~V}$ ). Retention time was $3.5-4 \mathrm{~min}$. 5-HT values were calculated by reference to standard curves run daily.

\section{Single-Unit Recordings}

We examined the ability of VN2222 to suppress the firing activity of 5-HT neurons in the dorsal raphe nucleus in untreated rats. This was compared to that of the $5-\mathrm{HT}_{1 \mathrm{~A}}$ receptor agonist 8-OH-DPAT and the SSRI fluoxetine. The inhibitory effects of these agents on serotonergic firing rate were reversed by the administration of low doses of the 5$\mathrm{HT}_{1 \mathrm{~A}}$ receptor antagonist WAY $100635(5-10 \mu \mathrm{g} / \mathrm{kg}$ i.v.). In chronic experiments, we assessed the sensitivity of $5-\mathrm{HT}_{1 \mathrm{~A}}$ receptors by comparing the ability of 8 -OH-DPAT to suppress serotonergic cell firing in groups of rats pretreated with vehicle or VN2222 for 2 weeks after a washout period of 3 days.

Single-unit extracellular recordings were performed as previously described (Sawyer et al, 1985; Celada et al, 1996). Briefly, rats were anesthetized (chloral hydrate $400 \mathrm{mg} / \mathrm{kg}$ i.p.) and positioned in a stereotaxic apparatus. Additional doses of chloral hydrate $(60 \mathrm{mg} / \mathrm{kg})$ were administered i.v. Body temperature was maintained at $37^{\circ} \mathrm{C}$ throughout the experiment with a heating pad. All wound margins and points of contact between the animal and the stereotaxic apparatus were infiltrated with lidocaine solution (5\%). In order to minimize pulsation, the atlanto-occipital membrane was punctured to release some CSF. For recordings in the dorsal raphe nucleus, a burr hole of approximately $4 \times 4 \mathrm{~mm}^{2}$ was drilled over lambda and the sagital sinus was ligated, cut, and reflected. Single units in the dorsal raphe nucleus were recorded extracellularly with glass micropipettes pulled from 2.0-mm capillary glass (WPI, Saratosa, FL) on a Narishige PE-2 pipette puller (Narishige Scientific Instruments, Tokyo, Japan). Microelectrodes were filled with $2 \mathrm{M} \mathrm{NaCl}$. Typically, impedance was between 4 and $10 \mathrm{M} \Omega$. Descents were carried out along the midline. 5-HT neurons were recorded 5.1-5.8 $\mathrm{mm}$ below the brain surface and were identified according to electrophysiological criteria previously described (Wang and Aghajanian, 1977, 1982). They exhibited a regular spontaneous firing rate with frequencies of $0.4-2.0 \mathrm{~Hz}$, and $2-5 \mathrm{~ms}$ bi- or triphasic extracellular waveform.

Single-unit potentials were amplified with a Neurodata IR283 (Cygnus Technology Inc., Delaware Water Gap, PA), postamplified, and filtered with a Cibertec amplifier (Madrid, Spain), and computed on-line using a DAT 1401plus interface system Spike2 software (Cambridge Electronic Design, Cambridge, UK). Data were also recorded on audiotape for off-line reanalysis if necessary. After recording stable baseline spontaneous activity for at least $5 \mathrm{~min}, 8-\mathrm{OH}-\mathrm{DPAT}$, fluoxetine, or VN2222 were administered i.v. every $2 \mathrm{~min}$. Only one neuron per rat was recorded.

\section{Data and Statistical Analysis}

Microdialysis results are expressed as fmol/fraction (uncorrected for recovery) and shown in figures as percentages of basal values (individual means of four predrug fractions). Statistical analysis of drug effects on dialysate 5-HT was performed using one- or two-way analysis of variance (ANOVA) for repeated measures of raw data with time as repeated factor and dose or pretreatment as independent factor. Student's $t$-tests have been used where appropriate. Changes in firing rate were quantified by averaging the values in the second minute after drug injection and expressed as percentage of baseline. $\mathrm{EC}_{50}$ and $\mathrm{ED}_{50}$ values were calculated with the GraphPad Prism program (GraphPad software, San Diego, CA). Data are expressed as the mean \pm SEM. The number of animals in each group is given in figure legends. Statistical significance has been set at the 95\% confidence level (two tailed).

\section{RESULTS}

\section{In Vivo Effects of the Local and Systemic Administration of VN2222 on Extracellular 5-HT Concentration}

Baseline $5-\mathrm{HT}_{\text {ext }}$ values in striatum were $4.2 \pm 0.2 \mathrm{fmol} /$ fraction $(n=26)$. The local application of $\mathrm{VN} 2222(10-$ $300 \mu \mathrm{M}$, uncorrected for recovery) significantly increased 5$\mathrm{HT}_{\text {ext }}$ in dorsal striatum. The calculated $\mathrm{EC}_{50}$ value was $59 \mu \mathrm{M}$ (Figure 2). The systemic administration of VN2222 $(1,3$, and $10 \mathrm{mg} / \mathrm{kg} \mathrm{s.c.}$.) induced a long-lasting and dosedependent decrease of $5-\mathrm{HT}_{\text {ext }}$ in dorsal striatum reaching a maximum of $50 \%$ of baseline at $10 \mathrm{mg} / \mathrm{kg}(p<0.000001$, time factor; $p<0.000002$, time $\times$ dose interaction) (Figure 3a). Average values (fractions 7-13) were $101.2 \pm 2.2, \quad 92.7 \pm 6.4, \quad 72.6 \pm 4.7$, and $55.6 \pm 2.6 \%$ of baseline for controls, 1,3 , and $10 \mathrm{mg} / \mathrm{kg} \mathrm{VN} 2222$, respectively. In the presence of $1 \mu \mathrm{M}$ citalopram (to block locally 5-HT reuptake) baseline 5-HT values were $21.0 \pm 7.3 \mathrm{fmol} /$ fraction $(n=20)$. In this experimental condition, the s.c. administration of VN2222 induced a greater reduction of 5$\mathrm{HT}_{\text {ext }}$ (Figure $3 \mathrm{~b}$ ), which was also statistically significant $(p<0.000002$, dose factor; $p<0.000001$, time factor; $p<0.000001$, time $\times$ dose interaction). The average values (fractions 7-13) were $104.6 \pm 3.1,90.0 \pm 2.7,70.2 \pm 2.3$, 


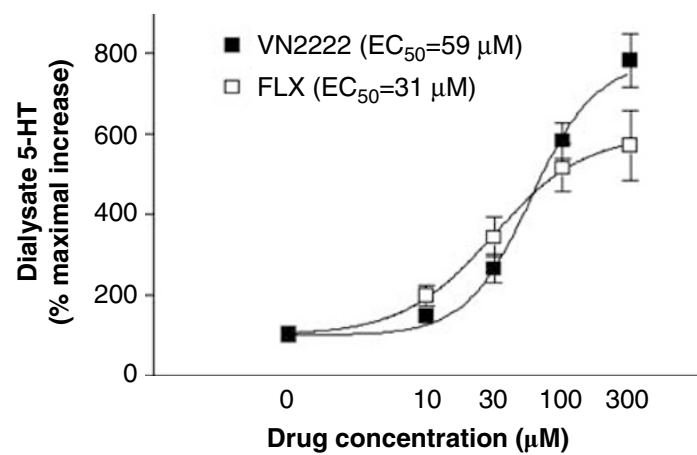

Figure 2 Increase of the extracellular 5-HT concentration in rat striatum produced by the local application of VN2222 using reverse dialysis $(n=6)$. Data points are means of the last two fractions at each concentration, expressed as percentage of baseline. For comparison, the effect of the local application of fluoxetine is also shown (adapted from Hervás and Artigas, 1998). The calculated $\mathrm{EC}_{50}$ values for VN2222 and fluoxetine were respectively, 59 and $31 \mu \mathrm{M}$ (uncorrected for recovery).
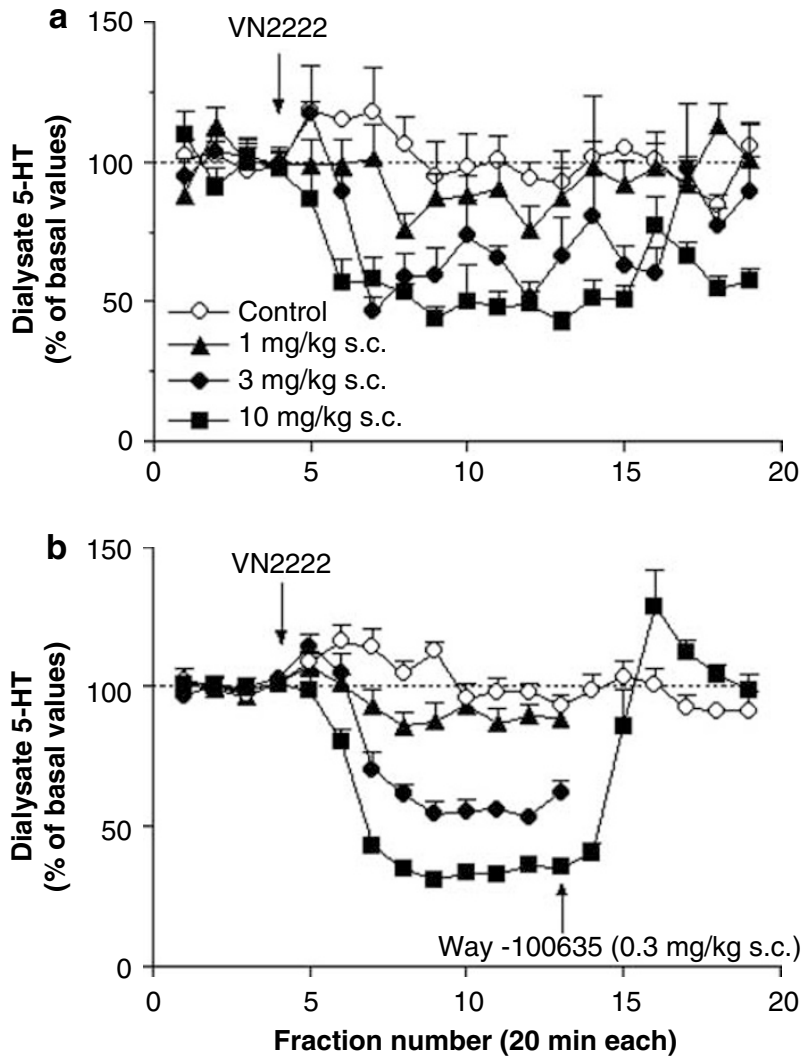

Figure 3 (a) Effect of the s.c. administration of $\mathrm{I}, 3$, and $10 \mathrm{mg} / \mathrm{kg}$ of VN2222 (arrow) on the extracellular 5-HT concentration in rat striatum ( $n=5-6$ rats/group). (b) Effect of the s.c. administration of 1,3 , and $10 \mathrm{mg} /$ $\mathrm{kg}$ of VN2222 (first arrow) on the extracellular 5-HT concentration in rat striatum ( $n=4-5$ rats/group) using a perfusion fluid containing I $\mu$ M of the reuptake inhibitor citalopram. The administration of the 5-HT IA receptor antagonist WAY 100635 (0.3 mg/kg s.c.; second arrow) reversed the inhibition of 5-HT release elicited by VN2222 $10 \mathrm{mg} / \mathrm{kg}$ s.c. See results for statistical analysis.

and $47.2 \pm 0.9 \%$ of baseline for controls, 1,3 , and $10 \mathrm{mg} / \mathrm{kg}$ VN2222, respectively. The reduction in $5-\mathrm{HT}_{\text {ext }}$ produced by $10 \mathrm{mg} / \mathrm{kg}$ VN2222 was fully counteracted by the adminis- tration of $0.3 \mathrm{mg} / \mathrm{kg}$ s.c. of the selective $5-\mathrm{HT}_{1 \mathrm{~A}}$ receptor antagonist WAY $100635(p<0.000001$; Figure $3 b)$.

\section{Single-Unit Recordings in Dorsal Raphe Serotonergic Neurons}

The i.v. administration of VN2222 reduced dose dependently the firing rate of identified 5-HT neurons in the dorsal raphe nucleus. Figure 4a shows an integrated firing rate histogram corresponding to the effects of cumulative doses of VN2222 (2-64 $\mu \mathrm{g} / \mathrm{kg}$ i.v.). Neuronal activity ceased in most neurons examined at $64-128 \mu \mathrm{g} / \mathrm{kg}$ i.v. VN2222. The calculated $\mathrm{ED}_{50}$ was $14.9 \mu \mathrm{g} / \mathrm{kg}$ i.v. (Figure $4 \mathrm{a}$ ). The effect of VN2222 was reversed by a low dose of WAY $100635(5 \mu \mathrm{g} / \mathrm{kg}$ i.v.; Figure 4a). Owing to the high affinity of VN2222 for the 5 -HT transporter and $5-\mathrm{HT}_{1 \mathrm{~A}}$ receptors, we also examined the effects of two reference compounds, fluoxetine and 8$\mathrm{OH}-\mathrm{DPAT}$ on 5-HT cell firing. Both inhibited the firing rate of dorsal raphe serotonergic neurons, with $\mathrm{ED}_{50}$ values of 790 and $0.76 \mu \mathrm{g} / \mathrm{kg}$ i.v., respectively (Figure $4 \mathrm{~b}$ ).

To examine whether VN2222 inhibited 5-HT neuronal firing by a direct action on $5-\mathrm{HT}_{1 \mathrm{~A}}$ receptors or indirectly, because of its ability to block 5-HT reuptake and increase 5$\mathrm{HT}_{\text {ext }}$ in the raphe nuclei (as an SSRI), we examined its effects on rats pretreated with the 5-HT synthesis inhibitor PCPA $(350 \mathrm{mg} / \mathrm{kg}, 2$ days before). The $5-\mathrm{HT}$ concentration in frontal cortex (wet tissue) was $764 \pm 33 \mathrm{pmol} / \mathrm{g}(n=6)$ in control rats and $56 \pm 8 \mathrm{pmol} / \mathrm{g}(n=7)$ in PCPA-treated rats (7\% of controls). In the latter group, VN2222 inhibited 5$\mathrm{HT}$ cell firing with an $\mathrm{ED}_{50}$ of $46.9 \mu \mathrm{g} / \mathrm{kg}$. Two-way ANOVA analysis of the data revealed a significant effect of VN2222 on cell firing $(p<0.0001)$ and a significant VN2222 $\times$ PCPA interaction $(p<0.03)$ (Figure $4 c)$. One neuron remained unaltered at a VN2222 dose of $64 \mu \mathrm{g} / \mathrm{kg}$ i.v. Omitting this neuron from the calculations resulted in an $\mathrm{ED}_{50}$ value of $27.1 \mu \mathrm{g} / \mathrm{kg}$ i.v. $(n=4)$ and a nonsignificant $(p=0.25)$ VN2222 $\times$ PCPA interaction.

\section{Effects of VN2222 on Postsynaptic 5-HT $\mathrm{HA}_{1 \mathrm{~A}}$ Receptors}

In conditions of blockade of the 5-HT reuptake, the local application of potent $5-\mathrm{HT}_{1 \mathrm{~A}}$ receptor agonists, such as 8OH-DPAT or BAY $\times 3702$, in medial prefrontal cortex reduced $5-\mathrm{HT}_{\text {ext }}$ (Casanovas et al, 1999a). This effect is attributable to an activation of postsynaptic $5-\mathrm{HT}_{1 \mathrm{~A}}$ receptors in this brain area since it was reversed by the coperfusion of WAY 100635 (Casanovas et al, 1999a). We used this experimental paradigm to assess the action of VN2222 at postsynaptic $5-\mathrm{HT}_{1 \mathrm{~A}}$ receptors. Given the $5-\mathrm{HT}$ reuptake blocking properties of VN2222, a maximal concentration of citalopram $(10 \mu \mathrm{M}$; Hervás et al, 2000) was used to block locally 5 -HT reuptake. In this experimental condition, the application of 8-OH-DPAT $(100 \mu \mathrm{M})$ significantly reduced $5-\mathrm{HT}_{\text {ext }}$ in medial prefrontal cortex compared to control rats, perfused with the dialysis fluid supplemented with $10 \mu \mathrm{M}$ citalopram $(p<0.00001$, time effect; $p<0.00001$, time $\times$ treatment interaction). The systemic administration of WAY $1006350.3 \mathrm{mg} / \mathrm{kg}$ s.c. reversed the inhibition of 5 -HT release produced by 8 -OH-DPAT application $(p<0.000001)$ (Figure 5). In control rats perfused with citalopram $10 \mu \mathrm{M}$, WAY $1006350.3 \mathrm{mg} / \mathrm{kg}$ s.c. increased $5-\mathrm{HT}_{\text {ext }}$ above baseline $(p<0.01)$. 

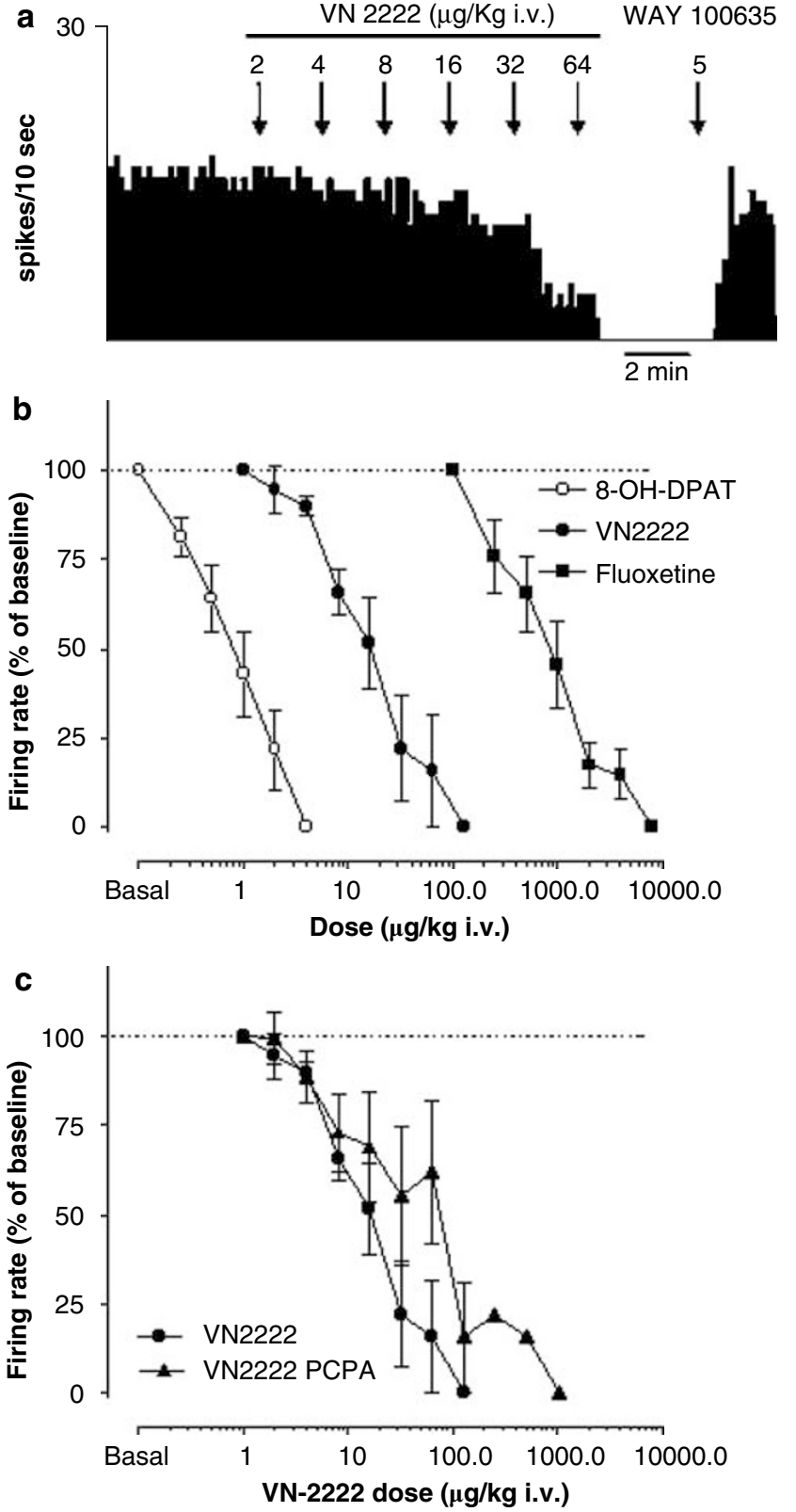

Figure 4 (a) Integrated firing rate histogram showing the effect of cumulative doses of VN2222 (arrows, up to $64 \mu \mathrm{g} / \mathrm{kg}$ i.v.) on the firing rate of a dorsal raphe $5-\mathrm{HT}$ neuron. The suppression of the firing rate produced by VN2222 was reversed by the administration of a low dose of the selective 5-HTIA receptor antagonist WAY 100635 (5 $\mu \mathrm{g} / \mathrm{kg}$ i.v.). (b) Dose-response curves of 8-OH-DPAT, VN2222, and fluoxetine to suppress firing rate of $5-\mathrm{HT}$ neurons in the dorsal raphe nucleus. The $\mathrm{ED}_{50}$ values were $0.76[0.62-0.94], \quad 14.9[7.1-31.5]$, and 790 [5901060] $\mu \mathrm{g} / \mathrm{kg}$ i.v., respectively ( $n=6-8 \mathrm{rats} / \mathrm{group} ; 95 \%$ confidence intervals in brackets). (c) Comparison of the effect of VN2222 on the firing rate of dorsal raphe serotonergic neurons in untreated $(n=7)$ or rats depleted of $5-\mathrm{HT}$ by the pretreatment with the 5-HT synthesis inhibitor PCPA $(n=5)$. See results for statistical analysis.

The application of VN2222 $(300 \mu \mathrm{M})$ reduced $5-\mathrm{HT}_{\text {ext }}$ in medial prefrontal cortex to an extent comparable to that produced by $100 \mu \mathrm{M} 8$-OH-DPAT $(p<0.0001$, time effect; $p<0.0002$, time treatment interaction). This effect was also attenuated by the s.c. administration of WAY 100635 $(p<0.01$; Figure 5$)$. In a small group of rats $(n=3)$, the

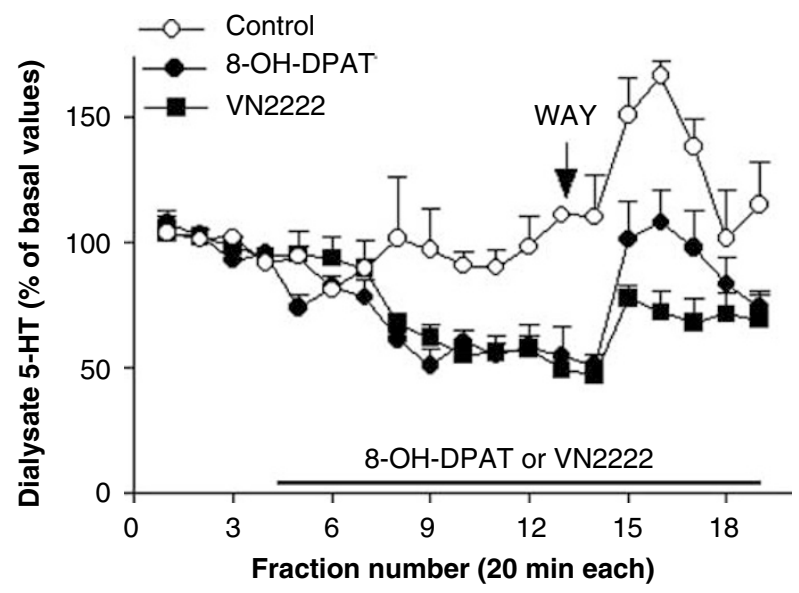

Figure 5 Effects of the local application of the selective $5-\mathrm{HT}_{\text {IA }}$ receptor agonist 8-OH-DPAT $(\mathrm{I} 00 \mu \mathrm{M})$ and VN2222 $(300 \mu \mathrm{M})$ on the extracellular 5-HT concentration in medial prefrontal cortex $(n=4$ and 8 , respectively). The 5-HT reduction elicited by 8-OH-DPAT and VN2222 was significantly counteracted by the s.c. administration of WAY 100635 (WAY; $0.3 \mathrm{mg} / \mathrm{kg}$ s.c.; arrow). Control rats $(n=3)$ were perfused with the dialysis fluid containing citalopram for the entire experiment and were also injected with WAY 100635, which significantly elevated 5-HT ext over baseline. The bar shows the period of drug application. See results for statistical analysis.

local application of VN2222 counteracted the increase in local 5-HT release induced by the selective stimulation of 5$\mathrm{HT}_{2 \mathrm{~A}}$ receptors in medial prefrontal cortex produced by the $5-\mathrm{HT}_{2}$ agonist DOI $100 \mu \mathrm{M}$ (DOI $=179 \pm 26 \%$ of baseline, DOI+VN2222 $=122 \pm 9 \%$ of baseline) (data not shown).

\section{Chronic Administration of VN2222: Desensitization of 5-HT ${ }_{1 \mathrm{~A}}$ Autoreceptors}

We examined the ability of VN2222 to desensitize 5- $\mathrm{HT}_{1 \mathrm{~A}}$ autoreceptors using two different experimental paradigms, in vivo microdialysis and single-unit recordings in the DR.

Rats treated with VN2222 (6 and $20 \mathrm{mg} / \mathrm{kg}$ day) had a weight gain that did not differ significantly from that of controls (mean values were: controls $74 \mathrm{~g}$, VN2222 $6 \mathrm{mg} / \mathrm{kg}$ day $83 \mathrm{~g}, \mathrm{VN} 222220 \mathrm{mg} / \mathrm{kg}$ day $85 \mathrm{~g}$ ). On day 15 , rats were implanted with dialysis probes in prefrontal cortex and allowed to recover from anesthesia for ca. 20-24h, before microdialysis experiments began. Dialysis probes were perfused with $10 \mu \mathrm{M}$ citalopram to block the 5-HT reuptake in medial prefrontal cortex. After collection of baseline values, rats were administered the selective $5-\mathrm{HT}_{1 \mathrm{~A}}$ receptor agonist 8-OH-DPAT $\left(25 \mu \mathrm{g} / \mathrm{kg}\right.$ s.c.). Baseline $5-\mathrm{HT}_{\text {ext }}$ values did not significantly differ between groups (one-way ANOVA) although there was a tendency towards lower values in VN2222-treated rats: $13.1 \pm 1.8 \mathrm{fmol} /$ fraction in controls, $9.4 \pm 1.8 \mathrm{fmol} /$ fraction in rats treated with VN2222 $6 \mathrm{mg} / \mathrm{kg}$ day, and $7.6 \pm 1.2 \mathrm{fmol} /$ fraction in those treated with VN2222 $20 \mathrm{mg} / \mathrm{kg}$ day. One-way ANOVA did not show a significant difference between controls and VN2222treated rats $\left(\mathrm{F}_{2,20}=2.55 ; p=0.10\right)$. The reduction in $5-\mathrm{HT}_{\text {ext }}$ induced by 8 -OH-DPAT was significantly less marked in rats pretreated with VN2222 than in controls (Figure 6). Two-way repeated measures ANOVA revealed a significant effect of time $(p<0.000001)$ and of the time $\times$ treatment interaction $(p<0.002)$. The injection of 8 -OH-DPAT reduced $5-\mathrm{HT}_{\text {ext }}$ maximally to $34 \pm 6,51 \pm 8$, and $55 \pm 7 \%$ of 


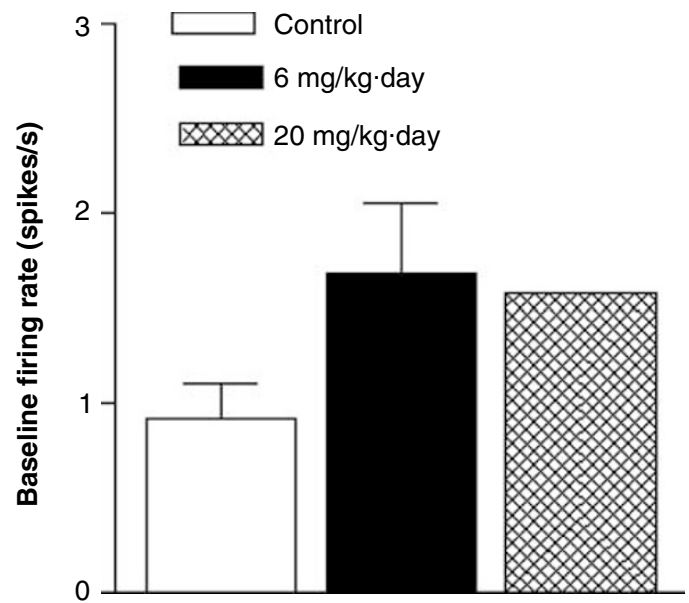

Figure 6 Effect of the administration of an 8-OH-DPAT challenge $(25 \mu \mathrm{g} / \mathrm{kg}$ s.c.) on the dialysate $5-\mathrm{HT}$ concentration in prefrontal cortex of rats pretreated with vehicle $(n=12), 2 \times 3 \mathrm{mg} / \mathrm{kg}$ day VN2222 $(n=5)$ and $2 \times 10 \mathrm{mg} / \mathrm{kg}$ day VN2222 $(n=6)$. Dialysis probes were perfused with artificial CSF containing $10 \mu \mathrm{M}$ of the 5-HT reuptake inhibitor citalopram. See results for statistical analysis.

baseline for controls, VN2222 $6 \mathrm{mg} / \mathrm{kg}$ day and VN2222 $20 \mathrm{mg} / \mathrm{kg}$ day, respectively.

After microdialysis experiments, rats were kept in their cages and, on the following day, the effects of the pretreatment with vehicle or $6 \mathrm{mg} / \mathrm{kg}$ day $\mathrm{VN} 2222$ on 5 $\mathrm{HT}_{1 \mathrm{~A}}$ receptor sensitivity were assessed by single-unit recordings of dorsal raphe 5-HT neurons. Once a stable recording was obtained for $5 \mathrm{~min}$, cumulative doses of 8OH-DPAT were injected $(0.25-32 \mu \mathrm{g} / \mathrm{kg}$ i.v. $)$ and individual dose-response curves were constructed (one neuron per rat). The baseline firing rate did not significantly differ among groups (Figure 7). This figure shows also the baseline firing of two neurons of rats treated with $20 \mathrm{mg} /$ $\mathrm{kg}$ day VN2222. Figure 8 shows representative firing rate histograms of neurons corresponding to the effects of 8OH-DPAT in controls and rats pretreated with $6 \mathrm{mg} / \mathrm{kg}$ day $\mathrm{VN} 2222$. The $\mathrm{ED}_{50}$ of 8-OH-DPAT for the vehicle-treated group was $0.45 \mu \mathrm{g} / \mathrm{kg}$ i.v. The corresponding value in rats treated with $6 \mathrm{mg} / \mathrm{kg}$ day VN2222 was $2.34 \mu \mathrm{g} / \mathrm{kg}$ i.v. Twoway ANOVA revealed a significant effect of the pretreatment (VN2222) $(p<0.002)$, dose (8-OH-DPAT) $(p<0.0001)$ and of the dose $\times$ pretreatment interaction $(p<0.0001)$ (Figure 8). In the two rats treated with $20 \mathrm{mg} / \mathrm{kg}$ day VN2222, 8-OH-DPAT elicited a moderate decrease of the firing rate at $32 \mu \mathrm{g} / \mathrm{kg}$ i.v. in one rat whereas in another rat, firing rate ceased at $4 \mu \mathrm{g} / \mathrm{kg}$ i.v. 8 -OH-DPAT.

To further examine the desensitization of $5-\mathrm{HT}_{1 \mathrm{~A}}$ autoreceptors induced by the chronic administration of VN2222, two groups of rats were treated with $6 \mathrm{mg} / \mathrm{kg}$ day VN2222 (as above) or vehicle for 14 days and microdialysis experiments were conducted on the 15th day ( $15 \mathrm{~h}$ after last dose). Baseline 5 -HT values were $2.6 \pm 0.2 \mathrm{fmol} /$ fraction in controls and $3.0 \pm 0.3 \mathrm{fmol} /$ fraction in rats treated with VN2222. The administration of a challenge dose of fluoxetine $(10 \mathrm{mg} / \mathrm{kg}$ i.p. $)$ elevated extracellular 5-HT significantly more in rats pretreated with $\mathrm{VN} 2222$ than in controls $(p<0.039$, group effect; $p<0.000001$, time effect; $p<0.01$, time $\times$ group interaction; Figure 9 ).

In an additional experiment we examined the effect of the sustained administration of $\mathrm{VN} 2222(6 \mathrm{mg} / \mathrm{kg}$ day) and

fluoxetine $(3 \mathrm{mg} / \mathrm{kg}$ day) on extracellular $5-\mathrm{HT}$ in prefrontal cortex using minipumps. Baseline 5-HT values were collected on the 14th day after implant, with the minipumps on board. The 5-HT values in the control groups for fluoxetine and for VN2222 did not differ significantly and were pooled to perform subsequent statistical analyses. Fluoxetine pretreatment increased dialysate $5-\mathrm{HT}$ by $79 \%$ $(7.5 \pm 0.7$ vs $4.2 \pm 0.3 \mathrm{fmol} /$ fraction; $p<0.00001)$ whereas VN2222 elicited a more moderate but still significant $33 \%$ increase $(5.6 \pm 0.5$ vs $4.2 \pm 0.3 \mathrm{fmol} /$ fraction; $p<0.015)$ (Table 1).

\section{DISCUSSION}

VN2222 is a new serotonergic agent with putative antidepressant properties. In agreement with its in vitro receptor profile (Martínez-Esparza et al, 2001; Table 2), the in vivo pharmacological properties of $\mathrm{VN} 2222$ are consistent with a dual action at the 5-HT transporter and 5$\mathrm{HT}_{1 \mathrm{~A}}$ receptors. Thus, it inhibits 5-HT reuptake in vivo with a potency slightly lower than that of fluoxetine. On the other hand, its neurochemical and electrophysiological actions in rat brain are consistent with those of a pre- and postsynaptic $5-\mathrm{HT}_{1 \mathrm{~A}}$ receptor agonist, in the dorsal raphe nucleus and the medial prefrontal cortex, respectively.

VN2222 increased $5-\mathrm{HT}_{\text {ext }}$ in the striatum when applied locally by reverse dialysis in the same concentration range as fluoxetine. The ratio between the respective $\mathrm{EC}_{50}$ values is $\sim 2(59 \mu \mathrm{M}$ for $\mathrm{VN} 2222,28-31 \mu \mathrm{M}$ for fluoxetine; Hervás and Artigas, 1998; Hervás et al, 2000). However, its systemic administration reduced $5-\mathrm{HT}_{\text {ext }}$ in the same brain area. The striatum was chosen because (together with prefrontal cortex) it is one of the brain areas where the 5-HT release is more sensitive to the activation of $5-\mathrm{HT}_{1 \mathrm{~A}}$ autoreceptors by direct and indirect (eg SSRI) agonists (Kreiss and Lucki, 1994; Casanovas et al, 1997; Romero and Artigas, 1997; Casanovas et al, 2000). The discrepancy between the effects of the local (5-HT increase) and systemic administration (5-HT decrease) of VN2222 is likely accounted for by its 
Control

a

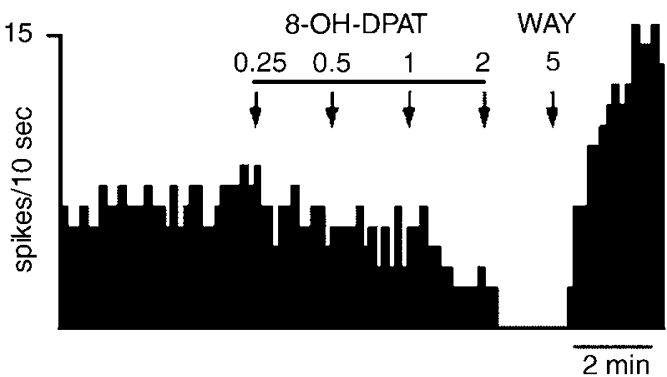

$\mathrm{VN}-22226 \mathrm{mg} / \mathrm{kg} \cdot \mathrm{day}$
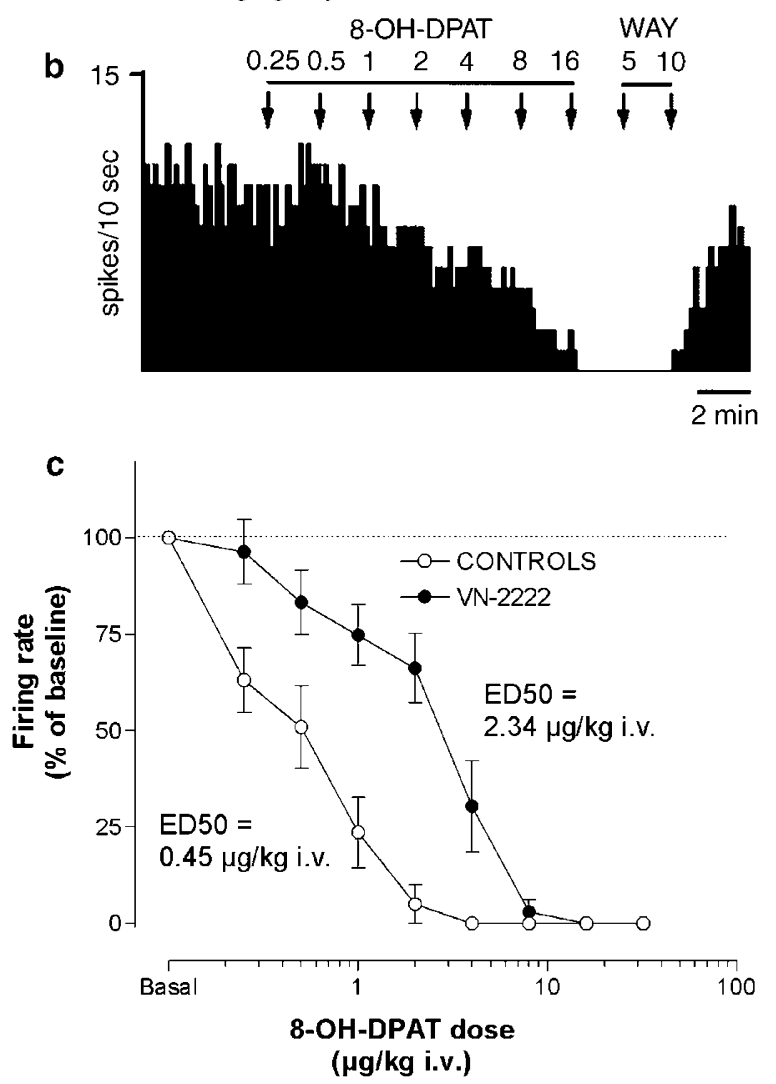

Figure 8 Integrated firing rate histograms corresponding to the effects of cumulative doses of $8-\mathrm{OH}-\mathrm{DPAT}$ (arrows, in $\mu \mathrm{g} / \mathrm{kg}$ i.v.) on two representative dorsal raphe 5 -HT neurons from rats treated with vehicle (a) and VN2222 (6 mg/kg day). (b) The suppression of serotonergic cell firing induced by 8-OH-DPAT was reversed by a low dose of WAY 100635 (WAY; 5-10 $\mu \mathrm{g} / \mathrm{kg}$ i.v.). (c) Dose-response curves of the suppressing effect of 8-OH-DPAT on the firing of dorsal raphe 5-HT neurons in rats treated with vehicle $(n=7)$ and $6 \mathrm{mg} / \mathrm{kg}$ day VN2222 $(n=5)$. The calculated $\mathrm{ED}_{50}$ values were $0.45[0.37-0.54]$ and 2.34 [1.87$2.92] \mu \mathrm{g} / \mathrm{kg}$ i.v., respectively ( $95 \%$ confidence intervals given in brackets).

agonist effect at raphe $5-\mathrm{HT}_{1 \mathrm{~A}}$ autoreceptors. This action would reduce $5-\mathrm{HT}_{\text {ext }}$ to an extent larger than the potential increase produced by systemic reuptake blockade. Indeed, the systemic administration of 5-HT uptake inhibitors activates a $5-\mathrm{HT}_{1 \mathrm{~A}}$ autoreceptor-mediated negative feedback that offsets the increase in forebrain $5-\mathrm{HT}_{\text {ext }}$ produced by reuptake blockade (Adell and Artigas, 1991; Artigas et al, 1996). Hence, the systemic administration of SSRIs reduces $5-\mathrm{HT}_{\text {ext }}$ when the 5-HT reuptake is locally blocked, an action that illustrates their 5 -HT release-reducing properties

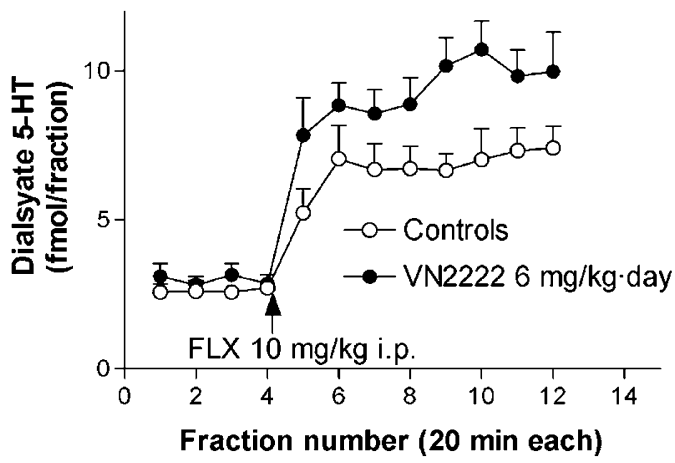

Figure 9 Effect of the administration of a fluoxetine challenge $(10 \mathrm{mg} / \mathrm{kg}$ i.p., arrow) on the extracellular 5-HT in the medial prefrontal cortex of rats treated with vehicle (open circles; $n=7$ ) or VN2222 $6 \mathrm{mg} / \mathrm{kg}$ day (filled circles; $n=8$ ). Two-way repeated measures ANOVA showed a significant effect of the group, time, and time $\times$ group interaction (see text for statistical details).

Table I Dialysate 5-HT Levels in the Prefrontal Cortex of Rats Treated with Fluoxetine $3 \mathrm{mg} / \mathrm{kg}$ day and VN2222 $6 \mathrm{mg} / \mathrm{kg}$ day with Minipumps for 2 Weeks

\begin{tabular}{ll}
\hline Treatment & 5-HT (fmol/fraction) \\
\hline Vehicle (50\% DMSO) & $3.8 \pm 0.3(6)$ \\
Vehicle (DMSO) & $4.5 \pm 0.3(7)$ \\
All controls & $4.2 \pm 0.3(13)$ \\
Fluoxetine 3 mg/kg day (50\% DMSO) & $7.5 \pm 0.3(7)^{* *}$ \\
VN2222 6 mg/kg (DMSO) & $5.6 \pm 0.5(8)^{*}$ \\
\hline
\end{tabular}

Data are means \pm SEM of the number of rats shown in brackets. $* p<0.05$ vs all controls ( $p=0.09$ vs DMSO controls). $* * x<0.000$ I vs all controls.

Table 2 Summary of the In Vitro Affinities of VN2222

\begin{tabular}{lc}
\hline Receptor & $\boldsymbol{K}_{\boldsymbol{i}}(\mathbf{n M})$ \\
\hline $5-H T$ transporter & $20 \pm 2.3$ \\
$5-H T_{1 A}$ & $20 \pm 2.5$ \\
$5-H T_{1 D}$ & $2650 \pm 110$ \\
$5-H T_{3}$ & $>5000$ \\
$5-H T_{2 A}$ & $250 \pm 25$ \\
$5-H T_{2 C}$ & $230 \pm 24$ \\
Dopamine $\mathrm{D}_{2}$ & $150 \pm 10$ \\
Adrenoceptor $\alpha_{1}$ & $35 \pm 9.3$ \\
Adrenoceptor $\alpha_{2}$ & $2000 \pm 250$ \\
Adrenoceptor $\beta$ & $750 \pm 56$ \\
Muscarinic & $>5000$ \\
\hline
\end{tabular}

The values represent the mean \pm SEM from at least three independent experiments (modified after Martínez-Esparza et al, 200I).

(Rutter and Auerbach, 1993; Hjorth and Auerbach, 1994a; Romero and Artigas, 1997). This effect is because of the activation of raphe $5-\mathrm{HT}_{1 \mathrm{~A}}$ autoreceptors since it is antagonized by the local (in raphe) or systemic administration of WAY 100635 and other nonselective 5- $\mathrm{HT}_{1 \mathrm{~A}}$ antagonists (Hjorth and Auerbach, 1994a; Romero and Artigas, 1997). For SSRIs, the balance between the two opposite factors controlling forebrain $5-\mathrm{HT}_{\text {ext }}$ (inhibition of 5-HT reuptake $v s$ activation of $5-\mathrm{HT}_{1 \mathrm{~A}}$ autoreceptors) is favorable to the former, whereas in the case of VN2222, the latter action predominates. Thus, high doses of SSRIs 
increase $5-\mathrm{HT}_{\text {ext }}$ after single treatment whereas VN2222 reduces $5-\mathrm{HT}_{\text {ext }}$.

In the presence of $1 \mu \mathrm{M}$ citalopram in the dialysis fluid, VN2222 reduced $5-\mathrm{HT}_{\text {ext }}$ slightly more than in standard dialysis conditions and this effect was counteracted by WAY 100635. This supports the exclusive involvement of $5-\mathrm{HT}_{1 \mathrm{~A}}$ receptors in the reduction of $5-\mathrm{HT}$ release induced by VN2222. The dissimilar effects of SSRIs and VN2222 in the absence of citalopram, together with the fact that VN2222 reduced $5-\mathrm{HT}_{\text {ext }}$ in both experimental conditions, suggest that VN2222 has direct agonist properties at $5-\mathrm{HT}_{1 \mathrm{~A}}$ autoreceptors. This view is supported by the results of single-unit recording experiments, in which VN2222 suppressed serotonergic cell firing and this effect was reversed by WAY 100635. The difference in the i.v. and s.c. doses of WAY 100635 used in electrophysiogical and microdialysis experiments of the present study is consistent with previous data showing antagonism of $5-\mathrm{HT}_{1 \mathrm{~A}}$ receptormediated effects (Forster et al, 1995) and reflects differences in the bioavailability by both routes. Thus, maximal effects of i.v. WAY 100635 take place in 1-2 min whereas they occur at $40-60 \mathrm{~min}$ by the s.c. route. An additional reason to use low i.v. doses of WAY 100635 was the observation that in some instances, higher doses suppressed serotonergic cell firing, in agreement with previous observations (Martin et al, 1999). Although VN2222 shows an appreciable affinity for $\alpha_{1}$-adrenoceptors (Table 2) its suppressing effects on 5HT release and cell firing do not appear to be mediated by a blockade of the $\alpha_{1}$-adrenoceptor-mediated activation of 5HT neurons, as these effects are fully counteracted by WAY 100635.

The affinity of VN2222 for $5-\mathrm{HT}_{1 \mathrm{~A}}$ receptors is lower than that of 8-OH-DPAT (Martínez-Esparza et al, 2001). In agreement, the calculated $\mathrm{ED}_{50}$ of VN2222 to suppress 5-HT cell firing $(15 \mu \mathrm{g} / \mathrm{kg}$ i.v. $)$ is greater than that of $8-\mathrm{OH}-\mathrm{DPAT}$ $(0.76 \mu \mathrm{g} / \mathrm{kg}$ i.v. $)$ but comparable or lower than that of other $5-\mathrm{HT}_{1 \mathrm{~A}}$ receptor agonists, such as buspirone $(11 \mu \mathrm{g} / \mathrm{kg}$ i.v.; VanderMaelen et al, 1986), ipsapirone (30-125 $\mathrm{gg} / \mathrm{kg}$ i.v.; Basse-Tomusc and Rebec, 1986; Cox et al, 1993), or flesinoxan (21-108 $\mu \mathrm{g} / \mathrm{kg}$ i.v.; Gobert et al, 1995; Hadrava et al, 1995).

$5 \mathrm{HT}_{1 \mathrm{~A}}$ receptor agonists and 5-HT reuptake blockers inhibit directly and indirectly, respectively, the firing activity of serotonergic neurons (Scuvée-Moreau and Dresse, 1979; Quinaux et al, 1982; Sprouse and Aghajanian, 1986; Blier and de Montigny, 1987). Since VN2222 appears to display both activities in vivo, either could theoretically contribute to its firing-suppressant effects. However, the inhibition of 5-HT reuptake seems to play a minor role in this effect, since (a) the $\mathrm{ED}_{50}$ of VN2222 to suppress 5 -HT cell firing is 53 times lower than that of fluoxetine, whereas its $\mathrm{EC}_{50}$ to inhibit locally 5-HT reuptake is double that of fluoxetine and (b) VN2222 inhibited the serotonergic cell firing in rats depleted of 5-HT by pretreatment with the 5HT synthesis inhibitor PCPA. This drug abolishes the inhibitory activity of indirect $5-\mathrm{HT}_{1 \mathrm{~A}}$ receptor agonists, including 5-HT reuptake blockers and cocaine (Trulson and Crisp, 1986; Cunningham and Lakoski, 1990). There was some difference between the $\mathrm{ED}_{50}$ values in both situations but this was small and mostly because of the influence of one neuron that deviated from the average sensitivity and showed no inhibition at $64 \mu \mathrm{g} / \mathrm{kg}$ VN2222, which may be because of adaptive mechanisms in some 5-HT neurons after irreversible inhibition of tryptophan hydroxylase by PCPA.

The local application of 8-OH-DPAT and VN2222 in medial prefrontal cortex markedly reduced basal $5-\mathrm{HT}_{\text {ext }}$. These experiments were carried out in the presence of a maximal concentration of citalopram $(10 \mu \mathrm{M}$; Hervás et al, $2000)$ to mask completely the 5-HT uptake inhibition elicited by VN2222. It was hypothetized that in this experimental condition we would observe the putative 5$\mathrm{HT}_{1 \mathrm{~A}}$ receptor agonist action of $\mathrm{VN} 2222$, because the 5-HT reuptake was completely blocked by citalopram. In agreement with previous observations (Casanovas et al, 1999a), WAY 100635 antagonized the reduction induced by both agents, which supports the involvement of postsynaptic 5$\mathrm{HT}_{1 \mathrm{~A}}$ receptors in these effects. Interestingly, WAY 100635 administration increased $5-\mathrm{HT}_{\text {ext }}$ above baseline in control rats perfused with $10 \mu \mathrm{M}$ citalopram. This suggests that the 5 -HT elevation produced by this citalopram concentration was sufficient to activate postsynaptic $5-\mathrm{HT}_{1 \mathrm{~A}}$ receptors and self-attenuate 5-HT release. In the absence of citalopram, WAY 100635 administration does not increase 5-HT $\mathrm{H}_{\text {ext }}$ in this and other forebrain areas of unanesthetized rats (Invernizzi et al, 1997; Romero and Artigas, 1997; Hervás et al, 2000; Romero et al, unpublished observations).

The reduction in $5-\mathrm{HT}_{\text {ext }}$ in medial prefrontal cortex elicited by the local application of $5-\mathrm{HT}_{1 \mathrm{~A}}$ receptor agonists is because of the activation of postsynaptic $5-\mathrm{HT}_{1 \mathrm{~A}}$ receptors (Casanovas et al, 1999a; Celada et al, 2001). Pyramidal neurons in prefrontal cortex project to and control the activity of ascending 5-HT neurons in the dorsal raphe nucleus through the activation of $5-\mathrm{HT}_{1 \mathrm{~A}}$ and $5-\mathrm{HT}_{2 \mathrm{~A}}$ receptors (Sesack et al, 1989; Hajós et al, 1998; Peyron et al, 1998; Celada et al, 2001; Martín-Ruiz et al, 2001). Thus, the activation of $5-\mathrm{HT}_{1 \mathrm{~A}}$ receptors in pyramidal neurons results in neuronal hyperpolarization (Araneda and Andrade, 1991) and a reduction of the excitatory input onto ascending 5-HT neurons (Celada et al, 2001), which decreases firing-dependent 5-HT release. Thus, in common with selective $5-\mathrm{HT}_{1 \mathrm{~A}}$ agonists like 8-OH-DPAT or $\mathrm{BAY} \times 3702$, VN2222 displays agonist properties at postsynaptic $5-\mathrm{HT}_{1 \mathrm{~A}}$ receptors. Moreover, VN2222 counteracted the $5-\mathrm{HT}_{2 \mathrm{~A}}$ receptor-mediated elevation in $5-\mathrm{HT}_{\text {ext }}$ induced by the local application of DOI, as observed previously for the potent $5-\mathrm{HT}_{1 \mathrm{~A}}$ receptor agonist $\mathrm{BAY} \times 3702$ (MartínRuiz et al, 2001). The agonism of VN2222 at cortical postsynaptic $5-\mathrm{HT}_{1 \mathrm{~A}}$ receptors may be important for its antidepressant effects in animal models of depression (Martínez-Esparza et al, 2001) because 5- $\mathrm{HT}_{1 \mathrm{~A}}$ receptor agonists show anxiolytic/antidepressant properties (Lucki et al, 1994; de Vry, 1995). In addition, electrophysiological data support that the activation of hippocampal $5-\mathrm{HT}_{1 \mathrm{~A}}$ receptors may be important for the antidepressant action (Blier and de Montigny, 1994; Haddjeri et al, 1998). However, the present data cannot establish whether VN2222 acts as a full or partial agonist in vivo at cortical $5-\mathrm{HT}_{1 \mathrm{~A}}$ receptors, yet the similar reduction of 5 - $\mathrm{HT}$ release elicited by VN2222 and 8-OH-DPAT suggests a substantial agonist effect of the former. Moreover, in hippocampal membranes, VN2222 inhibits the forskolin-induced cAMP formation with a potency lower than that of $8-\mathrm{OH}-\mathrm{DPAT}$ (Martínez-Esparza et al, 2001). 
The repeated administration of VN2222 resulted in a functional desensitization of $5-\mathrm{HT}_{1 \mathrm{~A}}$ autoreceptors, as assessed by in vivo microdialysis and single-unit recordings of dorsal raphe 5-HT neurons. The five-fold shift of the sensitivity of $5-\mathrm{HT}_{1 \mathrm{~A}}$ receptors produced by $6 \mathrm{mg} / \mathrm{kg}$ day VN2222 is greater than that produced by maximal doses of SSRIs and selective 5- $\mathrm{HT}_{1 \mathrm{~A}}$ receptor agonists (Haddjeri et al, 1999; Le Poul et al, 1995, 1999, 2000) and suggests a very efficient desensitization of $5-\mathrm{HT}_{1 \mathrm{~A}}$ autoreceptors controlling serotonergic cell firing. Interestingly, the baseline firing rate of rats treated chronically with VN2222 was higher, although not significantly different from controls, which suggests that 5-HT neurons had-at least - recovered their normal firing rate, in agreement with previous observations with other antidepressant drugs (Blier and de Montigny, 1994).

Likewise, in microdialysis experiments, the 8-OH-DPAT challenge reduced 5-HT release significantly less in rats pretreated with VN2222, further supporting the view that this agent desensitized $5-\mathrm{HT}_{1 \mathrm{~A}}$ autoreceptors. In microdialysis experiments, only one dose of 8-OH-DPAT was used. Therefore, we could not determine whether the difference between controls and VN2222-treated rats was because of a change in potency or in maximal effect. However, the electrophysiological data suggest a change in potency. Similarly, a challenge dose of fluoxetine was able to induce a greater increase in $5-\mathrm{HT}_{\text {ext }}$ in rats pretreated with VN2222 than in controls, an observation that also supports the view that VN2222 effectively desensitized $5-\mathrm{HT}_{1 \mathrm{~A}}$ autoreceptors after repeated treatment for 2 weeks.

The increase in $5-\mathrm{HT}_{\text {ext }}$ produced by minipump administration of fluoxetine $3 \mathrm{mg} / \mathrm{kg}$ day is in agreement with previous data from this laboratory (Hervás et al, 2000), although the effect size was slightly lower in the present experiments because of higher baseline $5-\mathrm{HT}_{\text {ext }}$ values in controls. VN2222 produced a more moderate increase in 5$\mathrm{HT}_{\text {ext }}$ which was, however, statistically significant (Table 1). Again, since acute treatment with this daily dose reduced 5$\mathrm{HT}_{\text {ext }}$, this is an additional argument in favor of an effective desensitization of $5-\mathrm{HT}_{1 \mathrm{~A}}$ receptors by $\mathrm{VN} 2222$.

Taken together, electrophysiological and microdialysis experiments suggest that a 2-week VN2222 treatment markedly reduced the effectiveness of $5-\mathrm{HT}_{1 \mathrm{~A}}$ receptors controlling presynaptic serotonergic function. Moreover, (a) postsynaptic $5-\mathrm{HT}_{1 \mathrm{~A}}$ receptors in cortico-limbic areas are involved in the effects of systemically administered 8OH-DPAT (Ceci et al, 1994; Romero et al, 1994; Artigas et al, 1998; Hajós et al, 1999; Celada et al, 2001) and (b) these do not desensitize after prolonged treatments (Blier and de Montigny, 1994; Dong et al, 1997; Le Poul et al, 2000). Hence, it is possible that the actual sensitivity of raphe 5$\mathrm{HT}_{1 \mathrm{~A}}$ autoreceptors after repeated VN2222 treatment is actually lower than that determined in the present experiments using the systemic 8-OH-DPAT challenge.

The present data are in keeping with previous work showing that prolonged administration of $5-\mathrm{HT}_{1 \mathrm{~A}}$ receptor agonists and SSRIs desensitizes dorsal raphe $5-\mathrm{HT}_{1 \mathrm{~A}}$ autoreceptors (Blier and de Montigny, 1987, 1994; Hensler et al, 1991; Bohmaker et al, 1993; Invernizzi et al, 1994; Le Poul et al, 1995, 1999, 2000; Dong et al, 1997; Casanovas et al, 1999b; Hervás et al, 2000). However, some microdialysis studies have failed to observe such effects (Sharp et al, 1993;
Hjorth and Auerbach, 1994b; Auerbach and Hjorth, 1995; Bosker et al, 1995; Invernizzi et al, 1995). The origin of these discrepancies is unclear and may involve differences in drug half-lives of the agents used, route of administration (eg repeated injections $v s$ minipumps) and regional effects, since most of the latter studies were conducted in the hippocampus, mostly innervated by median raphe 5 - $\mathrm{HT}$ neurons. Our own microdialysis data, obtained in prefrontal cortex, are consistent with single-unit recordings in the dorsal raphe indicating a desensitization of $5-\mathrm{HT}_{1 \mathrm{~A}}$ receptors. More importantly, some microdialysis and single-unit data were obtained in the same animals, which reinforces the association between both measures. It should be mentioned that the present observations have been obtained with a relative low dose of VN2222 (6 mg/kg day). This is equivalent to $3 \mathrm{mg} / \mathrm{kg}$ day fluoxetine in terms of in vivo reuptake blockade and lower than the standard $10 \mathrm{mg} /$ $\mathrm{kg}$ day dose, which may appear too high compared with the standard clinical regimen $(20 \mathrm{mg} / \mathrm{day})$. It is thus possible that a more effective desensitization and/or greater $5-\mathrm{HT}_{\text {ext }}$ increments could have been obtained after repeated treatment with larger doses of fluoxetine and VN2222.

In summary, the present results show that VN2222 inhibits the 5-HT reuptake and is a direct agonist at preand postsynaptic $5-\mathrm{HT}_{1 \mathrm{~A}}$ receptors in vivo. SSRIs possess significant clinical antidepressant activity and experimental data support the involvement of postsynaptic $5-\mathrm{HT}_{1 \mathrm{~A}}$ receptors in their clinical action. VN2222 shares both pharmacological activities in vivo, and in particular, it behaves as a cortical 5- $\mathrm{HT}_{1 \mathrm{~A}}$ receptor agonist and effectively desensitizes $5-\mathrm{HT}_{1 \mathrm{~A}}$ autoreceptors. The therapeutic lag of SSRIs can be attributable to the $5-\mathrm{HT}_{1 \mathrm{~A}}$-autoreceptormediated impairment of serotonergic activity that follows reuptake blockade in the raphe (presynaptic component) and to the absence of a sufficient tone on postsynaptic 5-HT receptors (postsynaptic component). As 5- $\mathrm{HT}_{1 \mathrm{~A}}$ receptor desensitization progresses, the tone on postsynaptic receptors increases, which results in a therapeutic action. VN2222 shares with SSRIs the property of suppressing serotonergic activity (presynaptic component). Such a reduction may appear contradictory with the desired enhancement of the tone on postsynaptic 5-HT receptors demanded of antidepressant agents, which could potentially result in a greater latency to onset of action. However, recent evidence suggests that antidepressant drugs enhance neurogenesis in the rat hippocampus (Malberg et al, 2000), an effect possibly mediated by the activation of postsynaptic 5$\mathrm{HT}_{1 \mathrm{~A}}$ receptors (Gould, 1999). Moreover, blockade of $5-\mathrm{HT}_{2 \mathrm{~A}}$ neurotransmission by M100907 enhanced the antidepressant effects of fluoxetine in the DRL 72-S reinforcement schedule without concurrently increasing $5-\mathrm{HT}_{\text {ext }}$ (Marek et al, 2001). Since $5-\mathrm{HT}_{2 \mathrm{~A}}$ colocalize with $5-\mathrm{HT}_{1 \mathrm{~A}}$ receptors in pyramidal neurons of medial prefrontal cortex (Martín-Ruiz et al, 2001) and both mediate opposing effect on pyramidal cell excitability (Araneda and Andrade, 1991) these behavioral results suggest that the superior antidepressant effect of fluoxetine+M100907 is because of an enhanced 5- $\mathrm{HT}_{1 \mathrm{~A}}$-mediated transmission. VN2222 may activate postsynaptic $5-\mathrm{HT}_{1 \mathrm{~A}}$ receptors during a time when SSRIs exert little or no activation of such receptors, an action that may result in a more rapid and/or effective antidepressant action. 


\section{ACKNOWLEDGEMENTS}

Work supported by grants from the Fondo de Investigación Sanitaria (2001-1147) and Marató TV3. Financial support from VITA-INVEST SA is gratefully acknowledged. Llorenç Díaz-Mataix is recipient of a fellowship from the IDIBAPS. We thank Leticia Campa for her skillful technical assistance with HPLC analyses.

\section{REFERENCES}

Adell A, Artigas F (1991). Differential effects of clomipramine given locally or systemically on extracellular 5-hydroxytryptamine in raphe nuclei and frontal cortex. An in vivo microdialysis study. Naunyn-Schmiedebergs Arch Pharmacol 343: 237-244.

Adell A, Artigas F (1998). A microdialysis study of the in vivo release of $5-\mathrm{HT}$ in the median raphe nucleus of the rat. $\mathrm{Br} J$ Pharmacol 125: 1361-1367.

Araneda R, Andrade R (1991). 5-Hydroxytryptamine 2 and 5hydroxytryptamine $_{1 \mathrm{~A}}$ receptors mediate opposing responses on membrane excitability in rat association cortex. Neuroscience 40: 399-412.

Artigas F (1993). 5-HT and antidepressants: new views from microdialysis studies. Trends Pharmacol Sci 14: 262.

Artigas F, Hervás I, Casanovas JM (1998). Modulation of 5-HT release by pre- and postsynaptic $5-\mathrm{HT}_{1 \mathrm{~A}}$ receptors. Soc Neurosci Abstr 24: 1365.

Artigas F, Pérez V, Alvarez E (1994). Pindolol induces a rapid improvement of depressed patients treated with serotonin reuptake inhibitors. Arch Gen Psychiatry 51: 248-251.

Artigas F, Romero L, de Montigny C, Blier P (1996). Acceleration of the effect of selected antidepressant drugs in major depression by $5-\mathrm{HT}_{1 \mathrm{~A}}$ antagonists. Trends Neurosci 19: 378-383.

Auerbach SB, Hjorth S (1995). Effect of chronic administration of the selective serotonin (5-HT): uptake inhibitor citalopram on extracellular 5-HT and apparent autoreceptor sensitivity in rat forebrain in vivo. Naunyn-Schmiedebergs Arch Pharmacol 352: 597-606.

Bakish D, Hooper CL, Thornton MD, Wiens A, Miller CA, Thibaudeau CA (1997). Fast onset: an open study of the treatment of major depressive disorder with nefazodone and pindolol combination therapy. Int Clin Psychopharmacol 12: 9197.

Basse-Tomusk A, Rebec GV (1986). Ipsapirone depresses neuronal activity in the dorsal raphe nucleus and the hippocampal formation. Eur J Pharmacol 130: 141-143.

Bel N, Artigas F (1993). Chronic treatment with fluvoxamine increases extracellular serotonin in frontal cortex but not in raphe nuclei. Synapse 15: 243-245.

Berman RM, Darnell AM, Miller HL, Anand A, Charney DS (1997). Effect of pindolol in hastening response to fluoxetine in the treatment of major depression: a double-blind, placebo-controlled trial. Am J Psychiatry 154: 37-43.

Blier P, Bergeron R (1995). Effectiveness of pindolol with selected antidepressant drugs in the treatment of major depression. J Clin Psychopharmacol 15: 217-222.

Blier P, de Montigny C (1987). Modification of 5-HT neurone properties by sustained administration of the $5-\mathrm{HT}_{1 \mathrm{~A}}$ agonist gepirone: electrophysiological studies in the rat brain. Synapse 1: $470-480$.

Blier P, de Montigny C (1994). Current advances and trends in the treatment of depression. Trends Pharmacol Sci 15: 220-226.

Bohmaker K, Eison AS, Yocca FD, Meller E (1993). Comparative effects of chronic 8-OH-DPAT, gepirone and ipsapirone treatment on the sensitivity of somatodendritic 5-HT1A autoreceptors. Neuropharmacology 32: 527-534.
Bordet R, Thomas P, Dupuis B, Reseau de Recherche et d'Experimentation Psychopharmacologique (1998). Effect of pindolol on onset of action of paroxetine in the treatment of major depression: intermediate analysis of a double-blind, placebo-controlled trial. Am J Psychiatry 155: 1346-1351.

Bosker FJ, Vanesseveldt KE, Klompmakers AA, Westenberg HGM (1995). Chronic treatment with fluvoxamine by osmotic minipumps fails to induce persistent functional changes in central 5$\mathrm{HT}(1 \mathrm{~A})$ : and $5-\mathrm{HT}(1 \mathrm{~B})$ : receptors, as measured by in vivo microdialysis in dorsal hippocampus of conscious rats. Psychopharmacology 117: 358-363.

Casanovas JM, Berton O, Celada P, Artigas F (2000). In vivo actions of the selective $5-\mathrm{HT}_{1 \mathrm{~A}}$ receptor agonist $\mathrm{BAY} \times 3702$ on serotonergic cell firing and release. Naunyn-Schmiedebergs Arch Pharmacol 362: 248-254.

Casanovas JM, Hervás I, Artigas F (1999a). Postsynaptic 5-HT $1 \mathrm{~A}$ receptors control 5 -HT release in the rat medial prefrontal cortex. Neuroreport 10: 1441-1445.

Casanovas JM, Lésourd M, Artigas F (1997). The effect of the selective $5-\mathrm{HT}_{1 \mathrm{~A}}$ agonists alnespirone (S-20499) and $8-\mathrm{OH}-$ DPAT on extracellular 5-hydroxytryptamine in different regions of rat brain. Br J Pharmacol 122: 733-741.

Casanovas JM, Vilaro MT, Mengod G, Artigas F (1999b). Differential regulation of somatodendritic serotonin $5-\mathrm{HT}_{1 \mathrm{~A}}$ receptors by 2 -week treatments with the selective agonists alnespirone (S-20499) and 8-hydroxy-2-(di- $n$-propylamino)tetralin: microdialysis and autoradiographic studies in rat brain. $J$ Neurochem 72: 262-272.

Ceci A, Baschirotto A, Borsini F (1994). The inhibitory effect of 8$\mathrm{OH}-\mathrm{DPAT}$ on the firing activity of dorsal raphe neurons in rats is attenuated by lesion of the frontal cortex. Neuropharmacology 33: 709-713.

Celada P, Puig MV, Casanovas JM, Guillazo G, Artigas F (2001). Control of dorsal raphe serotonergic neurons by the medial prfrontal cortex: involvement of serotonin-1A, GABAA and glutmate receptors. J Neurosci 21: 9917-9929.

Celada P, Siuciak JA, Tran TM, Altar CA, Tepper JM (1996). Local infusion of brain derived neurotrophic factor modifies the firing pattern of dorsal raphé serotonergic neurons. Brain Res 712: 293-298.

Corradetti R, Laaris N, Hamoun N, Laporte AM, Le Poul E, Hamon $M$ et al (1998). Antagonist properties of (-)pindolol and WAY 100635 at somatodendritic and postsynaptic $5-\mathrm{HT}_{1 \mathrm{~A}}$ receptors in the rat brain. Br J Pharmacol 123: 449-452.

Cox RF, Meller E, Waszczak BL (1993). Electrophysiological evidence for a large receptor reserve for inhibition of dorsal raphe neuronal firing by 5- $\mathrm{HT}_{1 \mathrm{~A}}$ agonists. Synapse 14: 297-304.

Cunningham KA, Lakoski JM (1990). The interaction of cocaine with serotonin dorsal raphe neurons. Single-unit extracellular recording studies. Neuropsychopharmacology 3: 41-50.

Danish University Antidepressant Group (1986). Citalopram: clinical effect profile in comparison with clomipramine. A controlled multicenter study. Psychopharmacology 90: 131-138.

Danish University Antidepressant Group (1990). Paroxetine: a selective serotonin reuptake inhibitor showing better tolerance, but weaker antidepressant effect than clomipramine in a controlled multicenter study. J Affect Disord 18: 289-299.

De Vry J (1995). 5- $\mathrm{HT}_{1 \mathrm{~A}}$ receptor agonists: recent developments and controversial issues. Psychopharmacology 121: 1-26.

Dong J, de Montigny C, Blier P (1997). Effect of acute and repeated versus sustained administration of the $5-\mathrm{HT}_{1 \mathrm{~A}}$ receptor agonist ipsapirone: electrophysiological studies in the rat hippocampus and dorsal raphe. Naunyn-Schmiedebergs Arch Pharmacol 356: 303-311.

Forster EA, Cliffe IA, Bill DJ, Dover GM, Joones D, Reilly Y et al (1995). A pharmacological profile of the selective silent 5- $\mathrm{HT}_{1 \mathrm{~A}}$ receptor antagonist, WAY-100635. Eur J Pharmacol 281: $81-88$. 
Gobert A, Lejeune F, Rivet JM, Audinot V, Newman-Tancredi A, Millan MJ (1995). Modulation of the activity of central serotoninergic neurons by novel serotonin(1A) receptor agonists and antagonists: a comparison to adrenergic and dopaminergic neurons in rats. J Pharmacol Exp Ther 273: 1032-1046.

Gould E (1999). Serotonin and hippocampal neurogenesis. Neuropsychopharmacology 21: S46-S51.

Haddjeri N, Blier P, de Montigny C (1998). Long-term antidepressant treatments result in a tonic activation of forebrain 5-HT1a receptors. J Neurosci 18: 10150-10156.

Haddjeri N, Ortemann C, de Montigny C, Blier P (1999). Effect of sustained administration of the $5-\mathrm{HT}_{1 \mathrm{~A}}$ receptor agonist flesinoxan on rat 5-HT neurotransmission. Eur Neuropsychopharmacol 9: 427-440.

Hadrava V, Blier P, Dennis T, Ortemann C, de Montigny C (1995). Characterization of 5-hydroxytryptamine(1A) properties of flesinoxan: in vivo electrophysiology and hypothermia study. Neuropharmacology 34: 1311-1326.

Hajos M, Hajos-Korsok E, Sharp T (1999). Role of the medial prefrontal cortex in 5-HT1A receptor-induced inhibition of 5-HT neuronal activity in the rat. Br J Pharmacol 126: 1741-1750.

Hajós M, Richards CD, Szekely AD, Sharp T (1998). An electrophysiological and neuroanatomical study of the medial prefrontal cortical projection to the midbrain raphe nuclei in the rat. Neuroscience 87: 95-108.

Hensler JG, Covachich A, Frazer A (1991). A quantitative autoradiographic study of serotonin1A receptor regulation. Effect of 5,7-dihydroxytryptamine and antidepressant treatments. Neuropsychopharmacology 4: 131-144.

Hervás I, Artigas F (1998). Effect of fluoxetine on extracellular 5hydroxytryptamine in rat brain Role of 5-HT autoreceptors. Eur J Pharmacol 358: 9-18.

Hervás I, Queiroz C, Adell A, Artigas F (2000). Role of uptake inhibition and autoreceptor activation in the control of 5-HT release in the frontal cortex and dorsal hippocampus of the rat. Br J Pharmacol 130: 160-166.

Hervás I, Vilaró T, Romero L, Scorza C, Mengod G, Artigas F (2001). Desensitization of $5-\mathrm{HT}_{1 \mathrm{~A}}$ receptors by a low fluoxetine dose. Effect of the concurrent administration of WAY-100635. Neuropsychopharmacology 24: 11-20.

Hirani E, Opackajuffry J, Gunn R, Khan I, Sharp T, Hume S (2000). Pindolol occupancy of $5-\mathrm{HT}_{1 \mathrm{~A}}$ receptors measured in vivo using small animal positron emission tomography with carbon-11 labeled WAY 100635. Synapse 36: 330-341.

Hjorth S, Auerbach SB (1994a). Further evidence for the importance of $5-\mathrm{HT}_{1 \mathrm{~A}}$ autoreceptors in the action of selective serotonin reuptake inhibitors. Eur J Pharmacol 260: 251-255.

Hjorth S, Auerbach SB (1994b). Lack of 5-HT(1A): autoreceptor desensitization following chronic citalopram treatment, as determined by in vivo microdialysis. Neuropharmacology 33: 331-334.

Invernizzi R, Bramante M, Samanin R (1994). Chronic treatment with citalopram facilitates the effect of a challenge dose on cortical serotonin output: role of presynaptic $5-\mathrm{HT}_{1 \mathrm{~A}}$ receptors. Eur J Pharmacol 260: 243-246.

Invernizzi R, Bramante M, Samanin R (1995). Extracellular concentrations of serotonin in the dorsal hippocampus after acute and chronic treatment with citalopram. Brain Res 696: 6266.

Invernizzi R, Velasco C, Bramante M, Longo A, Samanin R (1997). Effect of $5-\mathrm{HT}_{1 \mathrm{~A}}$ receptor antagonists on citalopram-induced increase in extracellular serotonin in the frontal cortex, striatum and dorsal hippocampus. Neuropharmacology 36: 467-473.

Kreiss DS, Lucki I (1994). Differential regulation of 5-HT release in the striatum and hippocampus by $5-\mathrm{HT}_{1 \mathrm{~A}}$ autoreceptors of the dorsal and median raphe nuclei. J Pharmacol Exp Ther 269: $1268-1279$.
Kreiss DS, Lucki I (1995). Effects of acute and repeated administration of antidepressant drugs on extracellular levels of 5-hydroxytryptamine measured in vivo. J Pharmacol Exp Ther 274: 866-876.

Le Poul E, Boni C, Hanoun N, Laporte AM, Laaris N, Chauveau J et al (2000). Differential adaptation of brain $5-\mathrm{HT}_{1 \mathrm{~A}}$ and $5-\mathrm{HT}_{1 \mathrm{~B}}$ receptors and 5-HT transporter in rats treated chronically with fluoxetine. Neuropharmacology 39: 110-122.

Le Poul E, Laaris N, Doucet E, Fattaccini CM, Mocaër E, Hamon M et al (1999). Chronic alnespirone-induced desensitization of somatodendritic $5-\mathrm{HT}_{1 \mathrm{~A}}$ autoreceptors in the rat dorsal raphe nucleus. Eur J Pharmacol 365: 165-173.

Le Poul E, Laaris N, Doucet E, Laporte AM, Hamon M, Lanfumey L (1995). Early desensitization of somato-dendritic $5-\mathrm{HT}_{1 \mathrm{~A}}$ autoreceptors in rats treated with fluoxetine or paroxetine. NaunynSchmiederbgs Arch Pharmacol 352: 141-148.

Lucki I, Singh A, Kreiss DS (1994). Antidepressant-like behavioral effects of serotonin receptor agonists. Neurosci Biobehav Rev 18: 85-95.

Maes M, Libbrecht I, van Hunsel F, Campens D, Meltzer HY (1999). Pindolol and mianserin augment the antidepressant activity of fluoxetine in hospitalized major depressed patients, including those with treatment resistance. J Clin Psychopharmacol 19: 177-182.

Maes M, Vandoolaeghe E, Desnyder R (1996). Efficacy of treatment with trazodone in combination with pindolol or fluoxetine in major depression. J Affect Disord 41: 201-210.

Malberg JE, Eisch AJ, Nestler EJ, Duman RS (2000). Chronic antidepressant treatment increases neurogenesis in adult rat hippocampus. J Neurosci 20: 9104-9910.

Marek GJ, Martín-Ruiz R, Abo A, Artigas F (2001). Synergistic 'antidepressant-like' action between a highly selective $5-\mathrm{HT}_{2 \mathrm{~A}}$ antagonist (M100907) and the SSRI fluoxetine on DRL 72-S schedule. Soc Neurosci Abstr, (Abstract 975.8).

Martin LP, Jackson DM, Wallsten C, Waszczak BL (1999). Electrophysiological comparison of 5-hydroxytryptamine(1A) receptor antagonists on dorsal raphe cell firing. J Pharmacol Exp Ther 288: 820-826.

Martinez D, Hwang D, Mawlawi O, Slifstein M, Kent J, Simpson N et al (2001). Differential cccupancy of somatodendritic and postsynaptic $5 \mathrm{HT}(1 \mathrm{~A})$ receptors by pindolol. A dose-occupancy study with [ $\left.{ }^{11} \mathrm{C}\right]$ WAY 100635 and positron emission tomography in humans. Neuropsychopharmacology 24: 209-229.

Martínez-Esparza J, Oficialdegui A, Pérez-Silanes S, Heras B, Orús L, Palop JA et al (2001). A New 1-(aryl)-3-[4-(aryl)piperazin-1yl]-propane derivatives with dual action at $5-\mathrm{HT}_{1 \mathrm{~A}}$ serotonin receptors and serotonin transporter as a new class of antidepressants. J Med Chem 44: 418-428.

Martín-Ruiz R, Puig MV, Celada P, Shapiro D, Roth BL, Mengod G et al (2001). Control of serotonin release by $5-\mathrm{HT}_{2 \mathrm{~A}}$ receptors in medial prefrontal cortex. Involvement of glutamatergic transmission. J Neurosci 21: 9856-9866.

Moreno FA, Gelenberg AJ, Bachar K, Delgado PL (1997). Pindolol augmentation of treatment-resistant depressed patients. J Clin Psychiatry 58: 437-439.

Paxinos G, Watson C (1986). The Rat Brain in Stereotaxic Coordinates. Academic Press: Sydney.

Pérez V, Gilaberte I, Faries D, Alvarez E, Artigas F (1997). Randomised, double-blind, placebo-controlled trial of pindolol in combination with fluoxetine antidepressant treatment. Lancet 349: 1594-1597.

Pérez V, Soler J, Puigdemont D, Alvarez E, Grup de Recerca en Trastorns Afectius, Artigas F (1999). A double-blind, randomized, placebo-controlled trial of pindolol augmentation in depressive patients resistant to serotonin reuptake inhibitors. Arch Gen Psychiatry 56: 375-379.

Peyron C, Petit JM, Rampon C, Jouvet M, Luppi PH (1998). Forebrain afferents to the rat dorsal raphe nucleus demonstrated 
by retrograde and anterograde tracing methods. Neuroscience 82: $443-468$.

Quinaux N, Scuvée-Moreau J, Dresse A (1982). Inhibition of in vitro and ex vivo uptake of noradrenaline and 5-hydroxytryptamine by five antidepressants; correlation with reduction of spontaneous firing rate of central monoaminergic neurones. Naunyn-Schmiederbgs Arch Pharmacol 319: 66-70.

Rabiner EA, Gunn RN, Castro ME, Sargent PA, Cowen PJ, Koepp $\mathrm{MJ}$ et al (2000). Beta-blocker binding to human 5- $\mathrm{HT}_{1 \mathrm{~A}}$ receptors in vivo and in vitro: implications for antidepressant therapy. Neuropsychopharmacology 23: 285-293.

Romero L, Artigas F (1997). Preferential potentiation of the effects of serotonin uptake inhibitors by $5-\mathrm{HT}_{1 \mathrm{~A}}$ receptor antagonists in the dorsal raphe pathway: role of somatodendritic autoreceptors. J Neurochem 68: 2593-2603.

Romero L, Bel N, Artigas F, de Montigny C, Blier P (1996). Effect of pindolol on the function of pre- and postsynaptic $5-\mathrm{HT}_{1 \mathrm{~A}}$ receptors: in vivo microdialysis and electrophysiological studies in the rat brain. Neuropsychopharmacology 15: 349-360.

Romero L, Celada P, Artigas F (1994). Reduction of in vivo striatal 5-hydroxytryptamine release by 8 -OH-DPAT after inactivation of Gi/Go proteins in dorsal raphe nucleus. Eur J Pharmacol 265: 103-106.

Rutter JJ, Auerbach SB (1993). Acute uptake inhibition increases extracellular serotonin in the rat forebrain. J Pharmacol Exp Ther 265: 1319-1324.

Rutter JJ, Gundlah C, Auerbach SB (1994). Increase in extracellular serotonin produced by uptake inhibitors is enhanced after chronic treatment with fluoxetine. Neurosci Lett 171: 183-186.

Sawyer SF, Tepper JM, Young SJ, Groves PM (1985). Antidromic activation of dorsal raphé neurons from neostriatum: physiological characterization and effects of terminal autoreceptor activation. Brain Res 332: 15-28.

Scuvée-Moreau J, Dresse A (1979). Effect of various antidepressant drugs on the spontaneous firing rate of locur coeruleus and dorsal raphe neurons of the rat. Eur J Pharmacol 57: 219-225.

Sesack SR, Deutch AY, Roth RH, Bunney BS (1989). Topographical organization of the efferent projections of the medial prefrontal cortex in the rat: an anterograde tract-tracing study with Phaseolus vulgaris leucoagglutinin. J Comp Neurol 290: 213-242.
Sharp T, McQuade R, Bramwell S, Hjorth S (1993). Effect of acute and repeated administration of $5-\mathrm{HT}_{1 \mathrm{~A}}$ receptor agonists on 5HT release in rat brain in vivo. Naunyn-Schmiedebergs Arch Pharmacol 348: 339-346.

Sprouse JS, Aghajanian GK (1986). (-):-Propanolol blocks the inhibition of serotonergic dorsal raphe cell firing by $5-\mathrm{HT}_{1 \mathrm{~A}}$ selective agonists. Eur J Pharmacol 128: 295-298.

Tada K, Kasamo K, Ueda N, Suzuki T, Kojima T, Ishikawa K (1999). Anxiolytic 5-Hydroxytryptamine1A agonists suppress firing activity of dorsal hippocampus CA1 pyramidal neurons through a postsynaptic mechanism: single-unit study in unanesthetized, unrestrained rats. J Pharmacol Exp Ther 288: 843-848.

Tollefson GD, Holman SL, Sayler ME, Potvin JH (1994). Fluoxetine, placebo and tryciclic antidepressants in major depression with and without anxious features. J Clin Psychiatry 55: 50-59.

Tomé MB, Isaac MT, Harte R, Holland C (1997). Paroxetine and pindolol: a randomized trial of serotonergic autoreceptor blockade in the reduction of antidepressant latency. Int Clin Psychopharmacol 12: 81-89.

Trulson ME, Crisp T (1986). Do serotonin-containing dorsal raphe neurons possess autoreceptors? Exp Brain Res 62: 579-586.

VanderMaelen CP, Matheson GK, Wilderman RC, Patterson LA (1986). Inhibition of serotonergic dorsal raphe neurons by systemic and iontophoretic administration of buspirone, a nonbenzodiazepine anxiolytic drug. Eur J Pharmacol 129: 123-130.

Wang RY, Aghajanian GK (1977). Antidromically identified serotonergic neurons in the rat midbrain raphé: evidence for collateral inhibition. Brain Res 132: 186-193.

Wang RY, Aghajanian, GK (1982). Correlative firing patterns of serotonergic neurons in rat dorsal raphe nucleus. J Neurosci 2: $11-16$.

Zanardi R, Artigas F, Franchini L, Sforzini L, Gasperini M, Smeraldi E et al (1997). How long should pindolol be associated with paroxetine to improve the antidepressant response? J Clin Psychopharmacol 17: 446-450.

Zanardi R, Franchini L, Gasperini M, Lucca A, Smeraldi E, Pérez I (1998). Faster onset of action of fluvoxamine in combination with pindolol in the treatment of delusional depression: a controlled study. J Clin Psychopharmacol 18: 441-446. 